\title{
Analisis Pengendalian Kualitas untuk Mengurangi Produk Cacat pada Perusahaan
}

\author{
Fatma \\ (Program studi Manajemen Fakultas Ekonomi Unversitas Andi Djemma, \\ Email: fatma21@gmail.com)
}

Pembimbing: Andi Meriam, SE., MM \& Didi Haryono, S.Si., M.Si

\begin{abstract}
Abstrak
Penelitian ini bertujuan untuk menganalisis pengendalian kualitas untuk mengurangi produk cacat pada PT. Asera Tirta Posidonia Kota Palopo. Penelitian ini akan dilakukan pada PT. Asera Tirta Posidonia Kota Palopo dengan data yang digunakan yakni data sekunder. Permasalahan yang ada dalam penelitian ini akan dianalisis dengan menggunakan metode analisis deskriptif yaitu metode dengan cara mengumpulkan data dan mendeskriptifkan atau menjelaskan data-data tersebut berdasarkan kriteria-kriteria umum yang berlaku dan hal-hal yang ditemukan di lapangan. Dari hasil yang didapatkan bahwa pengendalian biaya kualitas untuk mengurangi produk cacat PT. Asera Tirta Posidonia Kota Palopo menggunakan analisis menghitung total biaya kualitas dan jumah optimal, menghitung total produk cacat/rusak, menghitung garis pusat Central Line (CL), menghitung batas kendali bawah atau Upper Control Limit (UCL), dan menghitung batas kendali bawah atau lower control limit (LCL) menunjukkan bahwa biaya kualitas yang tinggi mampu mengurangi produk cacat PT. Asera Tirta Posidonia Kota Palopo untuk tahun 2016 dengan total biaya kualitas Rp 27.854.052 dan jumlah produksi optimal sebesar 696.379 perdos setiap bulan.
\end{abstract}

Kata Kunci: pengendalian kualitas; produk catat; pengendalian proses.

\section{Pendahuluan}

Pesatnya perkembangan teknologi dan informasi membawa dampak terhadap tatanan kehidupan dunia. Perubahan yang tepat dan mendasar terjadi dalam kehidupan di segala bidang yang menuntut kebebasan interaksi antar kehidupan yang ada di dunia tanpa mengenal batas negara termasuk juga dalam kegiatan perdagangan dan bisnis. Salah satu konsekuensi logis dari perubahan dunia kearah globalisasi adalah adanya pergeseran cara pandang dalam pelaksanaan perdagangan internasional yang mengarah kepada perdagangan global.

Setiap industri dalam persaingan tinggi dituntut untuk berkompetisi dengan perusahaan lain dalam industri yang sejenis. Salah satu cara untuk memenangkan kompetisi atau paling tidak bertahan dalam kompetisi adalah dengan memberikan perhatian penuh terhadap kualitas produk yang dihasilkan oleh perusahaan sehingga dapat mengungguli produk yang dihasilkan oleh pesaing (Irwan \& Haryono, 2015). Hal ini mengakibatkan munculnya pasar bebas dunia yang pada 
gilirannya akan mengakibatkan meningkatnya persaingan di pasar internasional dan kaitannya dalam dunia bisnis maka masalah yang dihadapi perusahaan adalah semakin ketatnya persaingan. Oleh karena itu perusahaan harus dapat menjalankan strategi bisnisnya yang tepat agar mampu bertahan dalam menghadapi persaingan yang terjadi, hal yang terpenting yaitu dengan menjaga kualitas produksi (Didiharyono, 2016).

Perhatian pada kualitas memberikan dampak positif kepada bisnis melalui dua cara yaitu, dampak terhadap biaya-biaya produksi dan dampak terhadap pendapatan. Setiap usaha dalam persaingan tinggi selalu berkompetisi dengan industri yang sejenis. Agar bisa memenangkan kompetisi, pelaku bisnis harus memberikan perhatian penuh terhadap kualitas produk. Dampak terhadap biaya produksi terjadi melalui proses pembuatan produk yang memiliki derajat konformasi yang tinggi terhadap standar-standar sehingga bebas dari tingkat kerusakan yang mungkin (Arini, 2004). Dampak terhadap peningkatan pendapatan terjadi melalui peningkatan penjualan atas produk yang berkualitas yang berharga tinggi.

Perusahaan dalam proses produksinya harus memperhatikan kualitas agar menghasilkan produk yang bebas dari kerusakan. Hal ini dapat menghindarkan adanya pemborosan dan inefisensi sehingga biaya produksi per unit dapat ditekan dan harga produk dapat menjadi lebih kompetitif. Kualitas dari produk yang dihasilkan oleh suatu perusahaan ditentukan berdasarkan ukuran-ukuran dan karakteristik tertentu. Suatu produk dikatakan berkualitas baik apabila dapat memenuhi kebutuhan dan keinginan pelanggan atau dapat diterima oleh pelanggan sebagai batas spesifikasi, dan proses yang baik yang diberikan oleh produsen sebagai batas kontrol (Al Azhar, 2012).

Barang yang kualitas atau prosesnya jelek menurut produsen belum tentu ditolak oleh pelanggan, dan sebaliknya barang diluar batas kontrol produsen, karena merupakan barang yang rusak atau cacat tetapi oleh konsumen masih diterima. Sedangkan barang yang dikatakan baik oleh produsen tetapi sudah ditolak oleh konsumen karena di luar batas spesifikasi. Produk yang berkualitas akan memberikan keuntungan bisnis bagi produsen, dan tentunya juga dapat memberikan kepuasan bagi konsumen dan menghindari banyaknya keluhan para pelanggan setelah menggunakan produk yang dibelinya (Suti, 2011).

Gaspersz (2005), menyatakan bahwa dengan memberikan perhatian pada kualitas akan memberikan dampak yang positif kepada bisnis melalui dua cara yaitu dampak terhadap biaya produksi dan dampak terhadap pendapatan. Meskipun, proses produksi telah dilakukan dengan baik dan benar, pada kenyataan yang ada masih akan didapatkan produk cacat yang disebabkan oleh proses produksi tersebut. Dimana produk yang dihasilkan tidak sesuai dengan standar yang telah ditentukan sebelumnya. Hal ini dapat disebabkan karena adanya penyimpangan atau ketidaksesuaian standar dari berbagai faktor yang 
mendukung proses produksi tersebut seperti: bahan baku, tenaga kerja bahkan kualitas mesin yang digunakan dalam proses produksi.

Perusahaan dapat melakukan berbagai kegiatan yang akan berdampak terhadap peningkatan kualitas produksi untuk menghasilkan produk yang sesuai dengan kualitas yang diharapkan sehingga akan menurunkan tingkat produk cacat atau rusak. Selain itu, perusahaan harus selalu melakukan pengawasan dan peningkatan terhadap kualitas produknya, sehingga akan diperoleh hasil akhir yang optimal. Kualitas yang meningkat akan mengurangi terjadinya produk rusak sehingga mengakibatkan biaya-biaya yang terus menurun dan pada akhirnya meningkatkan laba.

Salah satu alat ukur yang dapat dipakai perusahaan utuk mengukur keberhasilan program perbaikan kualitas adalah dengan menggunakan biaya kualitas. Hal ini berkaitan dengan kebutuhan perusahaan yang harus selalu memantau dan melaporkan kemajuan dari program perbaikan tersebut. Apabila suatu perusahaan ingin melakukan program perbaikan kualitas, maka perusahaan harus mengidentifikasi biaya-biaya yang dikeluarkan pada masingmasing dari keempat kategori biaya dalam sistem pengendalian kualitas, untuk itu suatu perusahaan perlu membuat laporan biaya kualitas

Informasi yang ada dalam laporan biaya kualitas secara garis besar memberikan manfaat adalah: (a) Sebagai alat untuk mngukur kinerja, (b) sebagai alat analisis mutu proses, (c) Sebagai alat pemograman, (d) Sebagai alat penganggaran yaitu untuk membuat anggaran pengeluaran dalam mencapai program pehngendalian mutu, (e) Sebagai alat peramal yaitu untuk mengevaluasi dan menjamin prestasi produk dalam memenuhi persaingan pasar (Wahyuningtias, 2013).

PT. Asera Tirta Posidonia adalah merupakan salah satu perusahaan air minum dalam kemasan dengan merek asera. Dan demi memenuhi kebutuhan dan kepuasan pelanggan pimpinan dan seluruh staf PT. Asera Tirta Posidonia bertekad akan selalu memproduksi air Minum dalam kemasan sesuai dengan persyaratan standar secara kontinyu dan konsisten. PT.Asera terletak di Jalan Pongsimpin Kota Palopo.

Untuk melaksanakan sistem managemen mutu dengan baik dan optimal ditunjuk Quality Control sebagai managemen Representative (wakil managemen) karena segala seuatu yang berhubungan dengan managemen Mutu merupakan tanggung jawab dan wewenang pihaknya. Untuk melaksanakan tugas dan wewenang dibantu dengan beberapa Staf susuai dengan struktur yang ada. PT.Asera Tirta Posidonia untuk saat ini sudah memiliki banyak pelanggan tetap. Hal ini disebabkan karena Produk air kemasan asera memiliki kualitas Produk yang baik dan banyak disukai masyarakat khususnya di Kota Palopo (Didiharyono dkk, 2018).

Permasalahan yang di hadapi oleh perusahaan pada PT. Asera Tirta Posidonia yakni kendala-kendala perusahaan tersebut dari kurangnya bahan baku 
dan pasar persaingan yang luas terutama bagi penjualan air mineral. kemudian faktor yang menyebabkan suatu produk perusahaan tersebut mengalami kerusakan dalam produksi, yaitu berasal dari faktor tenaga kerja, mesin produksi, metode kerja , material/ bahan baku yang tidak sesuai standar, dan lingkungan kerja. Oleh karena itu, semua penyebab kerusakan dapat segera diperbaiki atau dilakukan pencegahaan sedini mungkin agar tidak terjadinya kerusakan yang besar lagi. Berdasarkan penjelasan diatas maka peneliti tertarik untuk melakukan penelitian ini yang bertujuan untuk menganalisis pengendalian Kualitas untuk Mengurangi Produk Cacat pada PT. Asera Tirta Posidonia Kota Palopo.

\section{Metode}

Penelitian ini akan dilakukan pada PT. Asera Tirta Posidonia Kota Palopo dengan data yang digunakan yakni data sekunder. Permasalahan yang ada dalam penelitian ini akan dianalisis dengan menggunakan metode analisis deskriptif yaitu metode dengan cara mengumpulkan data dan mendeskriptifkan atau menjelaskan data-data tersebut berdasarkan kriteria-kriteria umum yang berlaku dan hal-hal yang ditemukan di lapangan. Untuk menjawab permasalahan yang telah dikemukakan di atas maka perlu diambil langkah-langkah sebagai berikut:

1. Menghitung total biaya kualitas dan jumlah produk optimal

a. Menghitung total biaya kualitas dengan rumus.

$$
\mathrm{TQC}=\mathrm{QCC}+\mathrm{QAC}
$$

Dimana, TQC $=$ Total Quality Cost atau biaya kualitas total; $\mathrm{QCC}=$ Quality Cost Control atau biaya pencegahan dan penilaian; $\mathrm{QAC}=$ Quality Assurance Cost atau biaya kegagalan internal dan biaya kegagalan eksternal (Badri, 2012; Sari, 2018).

Biaya pengawasan kualitas dapat di hitung dengan menggunakan persamaan,

$$
\mathrm{QCC}=\frac{R \cdot o}{q}
$$

Sedangakn, biaya jaminan mutu dapat di hitung dengan persamaan,

$$
\mathrm{QAC}=c \cdot q
$$

Dimana, $\mathrm{R}=$ jumlah produk test; $\mathrm{o}=$ biaya pengetesan tiap kali test; $\mathrm{c}=$ biaya jaminan mutu.

b. Untuk jumlah produk yang rusak dengan biaya minimum atau jumlah produk optimal ( $\mathrm{Q}^{*}$ ) dapat di hitung dengan mengunakan persamaan,

$$
\mathrm{Q}^{*}=\sqrt{\frac{R \cdot o}{c}}
$$


2. Menghitung total produk cacat/ rusak yaitu dengan membuat histogram dan membuat peta kendali $p$ (Irwan, 2015; Haryono, 2017). Langkah-langkah dalam membuat peta kendali $p$ sebagai berikut:

- Menghitung garis pusat/ Central Line (CL). Garis pusat merupakan rata-rata kerusakan produk $(p)$.

$$
\begin{aligned}
& \text { Keterangan : } \\
& C L=\bar{P}=\frac{\sum p_{i}}{\sum n_{i}}
\end{aligned}
$$

$\sum n p$ : jumlah total yang rusak; dan $\sum n$ : jumlah total yang diperiksa

- Menghitang batas kendali bawah atau Upper Control Limit (UCL). Untuk menghitung batas kendali atas atau UCL dilakukan dengan rumus :

$$
U C L=\bar{P}+3 \sqrt{\frac{\bar{P}(1-\bar{P})}{n_{i}}}
$$

Keterangan, $\bar{P}$ : rata-rata ketidak sesuaian produk; dan $n$ : jumlah produksi

- Menghitung batas kendali bawah atau Lower Control Limit (LCL). Untuk menghitung batas kendali bawah atau LCL dilakukan dengan rumus:

$$
L C L=\bar{P}-3 \sqrt{\frac{\bar{P}(1-\bar{P})}{n_{i}}}
$$

Keterangan, $\bar{P}$ : rata-rata ketidak sesuaian produk; dan $n:$ jumlah produksi. Dengan catatan, jika LCL $<0$ maka LCL dianggap $=0$.

\section{Hasil dan Pembahasan}

\subsection{Hasil penelitian}

1. Menghitung total Pengendalian Biaya Kualitas

Biaya kualitas adalah Biaya mutu produk atau biaya kualitas adalah kegiatan mengidentifikasi semua biaya yang timbul berkaitan dengan upaya mengubah produk bermutu buruk (bad quality product) menjadi produk bermutu baik (good quality product). Biaya kualitas berkaitan dengan dua sub ketegori dari aktivitas yang berkaitan dengan kualitas, yaitu aktivitas kontrol dan aktivitas gagal. Aktivitas kontrol adalah aktivitas yang dilakukan oleh sebuah organisasi untuk menghindari atau mendeteksi kualitas buruk. Berikut akan ditentukan total biaya kualitas dan jumlah produk optimal yaitu

a. Total biaya kualitas yaitu :

$$
\begin{gathered}
\mathrm{TQC}=\mathrm{QCC}+\mathrm{QAC} \\
\mathrm{QCC}=\frac{(969938) \cdot(6500)}{211974}=\frac{63,045,970}{211974}=297.431273647
\end{gathered}
$$


QAC $=(130) .() 211974=27,556,620$

Sehingga, nilai TQC $=297.432+27,556,620=27,854,052$

Jadi total biaya kualitas yaitu Rp. 27.854.052

b. Jumlah produk optimal yaitu

$$
Q^{*}=\sqrt{\frac{(969938) \cdot(6500)}{130}}=696.379 \text { (perdos) }
$$

Jadi perhitungan diatas menyatankan bahwa biaya kualitas sebesar Rp 27.854.052 dan jumlah produk optimal kualitasnya sebesar 696,379. Hal ini bermakna bahwa dengan total biaya kualitas Rp. 27.854.052, dan jumlah produksi yang optimal sebesar 696.379 (perdos).

2. Menghitung total produk cacat

Mengumpulkan data menggunakan check sheet adalah mengumpulkan data produk rusak (check sheet). Data yang di peroleh dari perusahaan terutama data produksi dan data produk cacat kemudian diolah menjadi tabel yang rapi dan terstruktur. Hal ini di lakukan agar di memudahkan dalam memahami data tersebut hingga bisa dilakukan analisis lebih lanjut.

Mengunakan tabel (check sheet) ini berguna untuk mempermudah proses pengumpulkan data serta analisis. Data produksi yang menunjukan data produksi dan jumlah cacat selama 1 tahun hari kerja yaitu sebanyak 12 bulan beserta presentasenya sebagaimana ditunjukkan pada lampiran 2. Sedangkan histrogram digunakan meilhat banyaknya poduksi yang cacat dalam bentuk diagram batang sebagaimana digunakan pada Gambar 1 berikut

Tabel 1. Data laporan produksi dan produk cacat PT. Asera Tirta Posidonia Kota Palopo 2016

\begin{tabular}{|c|c|c|c|}
\hline Bulan & $\begin{array}{c}\text { Produksi } \\
(\mathrm{N})\end{array}$ & $\begin{array}{c}\text { Produksi Cacat } \\
(\mathrm{P})\end{array}$ & $\begin{array}{c}\text { Presentase Cacat Terhadap } \\
\text { Total Jumlah Produksi }\end{array}$ \\
\hline Januari & 85010 & 19056 & 1,96 \\
\hline Februari & 88103 & 37373 & 3,85 \\
\hline Maret & 73936 & 13847 & 1,42 \\
\hline April & 74100 & 14307 & 1,47 \\
\hline Mei & 73331 & 15078 & 1,55 \\
\hline Juni & 81320 & 13322 & 1,37 \\
\hline Juli & 59136 & 13488 & 1,39 \\
\hline Agustus & 74762 & 13340 & 1,37 \\
\hline September & 92265 & 14936 & 1,53 \\
\hline Oktober & 88611 & 15960 & 1,64 \\
\hline November & 100380 & 21744 & 2,24 \\
\hline Desember & 78984 & 19523 & 2,01 \\
\hline Jumlah & 969938 & 211974 & 21,85 \\
\hline
\end{tabular}


Berdasarkan Tabel 1 menujukkan data biaya produksi dan produk cacat pada PT. Asera tirta posidonia tahun 2016 selama 12 bulan total produksinya sebesar 969938 dan produk cacat sebesar 211974, dan rata-rata presentasinya $21,85 \%$. Jadi data tersebut di peroleh pada perusahan pada tahun 2016.

\section{a. Membuat histogram}

Histogram digunakan untuk melihat banyaknya produksi yang cacat dalam bentuk diagram batang agar mudah membaca atau menjelaskan dengan cepat maka data tersebut perlu untuk disajikan dalam bentuk histogram yang berupa alat penyajian data dalam bentuk grafis balok yang diperlihatkan pada gambar dibawah :

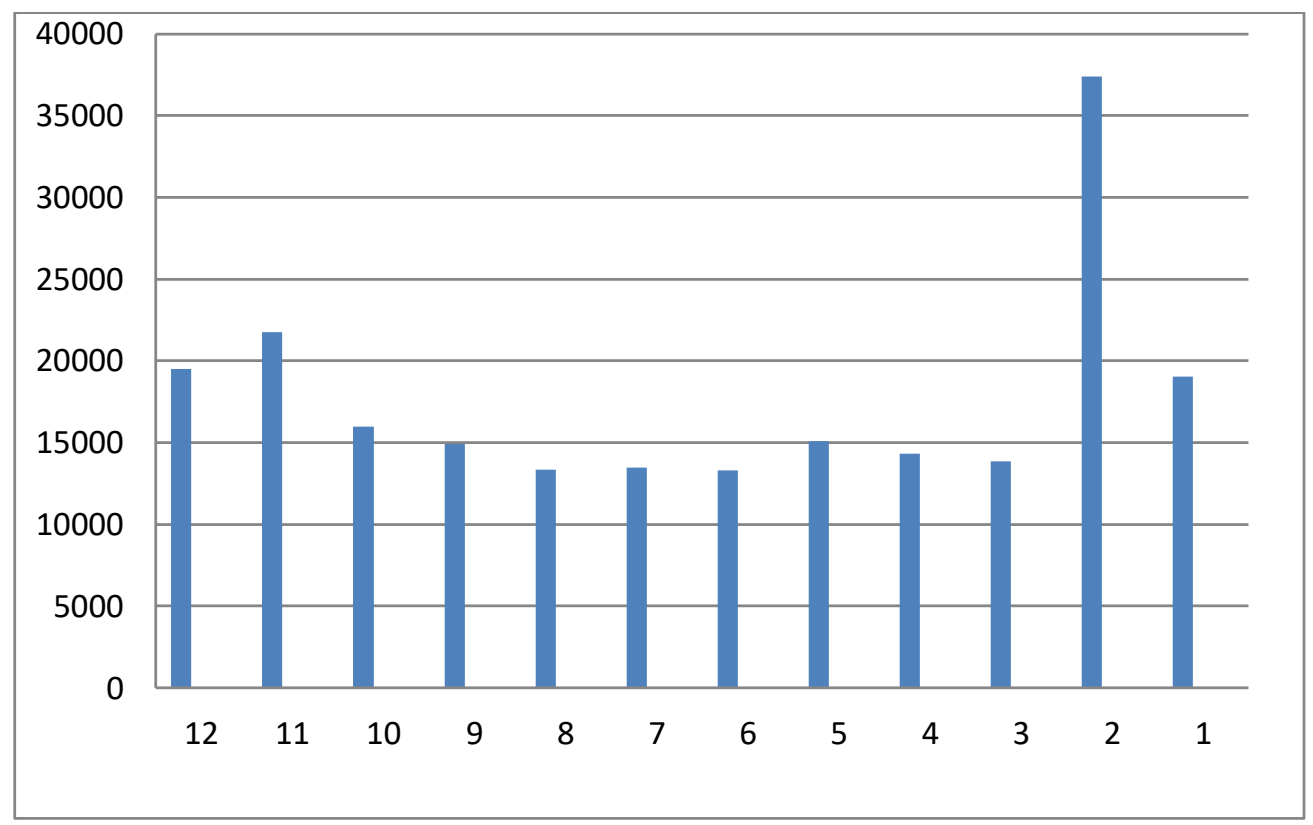

Gambar 1. Histogram

Dari hasil histogram diatas menunjukkan bahwa pada bulan 1 menampilkan produk cacat sebanyak 19056 dan pada bulan 2 terjadi kerusakan yang sangat parah pada produk tersebut sebanyak 37373 , bulan ke 3 sebanyak 13847, bulan ke 4 sebanyak 14307, bulan 5 sebanyak 15078, bulan 6 sebanyak 13322, selanjutnya pada bulan 7 sebanyak 13488, dan pada bulan 8 terjadi penurunan produk rusak yaitu sebanyak 13340, dan pada bulan 9 sebanyak 14936, dan pada bulan 10 sebanyak 15960, pada bulan 11 sebanyak 21744, dan pada bulan 12 sebanyak 19523 .

\section{b. Membuat peta kendali $p$}

Menghitung garis pusat / central line (LC). Garis pusat/ central line adalah garis tengah yang berada diantar batas kendali atas (UCL) dan batas kendali bawah (LCL). Garis pusat merupakan garis yang mewakili rata-rata tingkat kerusakan dalam suatu proses produksi. Untuk menghitung garis pusat di gunakan rumus : 
[60] Fatma, Artikel Ilmiah (Tugas Akhir), Prodi Manajemen Fakultas Ekonomi Unanda

$$
C L=\bar{P}=\frac{\sum p_{i}}{\sum n_{i}}=\frac{211974}{969938}=0,21
$$

Berdasarkan rumus maka di dapatkan Upper Control Limit ( UCL) untuk bulan periode 1 tahun sebagai berikut:

Untuk observasi yang pertama dengan sampel $U C L_{1}=85010$ dan $L C L_{1}=19056$ maka batas kendali adalah:

$$
\begin{array}{rrr}
U C L_{1}=\bar{P}+3 \sqrt{\frac{\bar{P}(1-\bar{P})}{n_{1}}} & L C L_{1}=\bar{P}-3 \sqrt{\frac{\bar{P}(1-\bar{P})}{n_{1}}} \\
=0,21+3 \sqrt{\frac{0,21(1-0,21)}{85010}} & =0,21-3 \sqrt{\frac{0,21(1-0,21)}{19056}} \\
=0,21419 & =0,20911
\end{array}
$$

Untuk observasi yang kedua dengan sampel $U C L_{2}=88103$ dan $L C L_{2}=37373$ maka batas kendali adalah:

$$
\begin{array}{rrr}
U C L_{2}=\bar{P}+3 \sqrt{\frac{\bar{P}(1-\bar{P})}{n_{2}}} & L C L_{2}=\bar{P}-3 \sqrt{\frac{\bar{P}(1-\bar{P})}{n_{2}}} \\
=0,21+3 \sqrt{\frac{0,21(1-0,21)}{88103}} & =0,21-3 \sqrt{\frac{0,21(1-0,21)}{37373}} \\
=0,14116 & =0,20365
\end{array}
$$

Dan seterusnya UCL dan LCL sebagai berikut dilampiran

Untuk observasi yang kesembilan sampel $U C L_{12}=78984$ dan $L C L_{12}=19523$ maka batas kendali adalah :

$$
\begin{gathered}
U C L_{12}=\bar{P}+3 \sqrt{\frac{\bar{P}(1-\bar{P})}{n_{12}}} \\
=0,21+3 \sqrt{\frac{0,21(1-0,21)}{78984}} \\
=0,21434
\end{gathered}
$$

$$
\begin{gathered}
L C L_{12}=\bar{P}-3 \sqrt{\frac{\bar{P}(1-\bar{P})}{n_{12}}} \\
=0,21-3 \sqrt{\frac{0,21(1-0,21)}{19523}} \\
=0,20125
\end{gathered}
$$

Tabel 2. Nilai Batas Atas (UCL) dan Batas Bawah ( LCL)

\begin{tabular}{|c|c|c|c|c|c|c|}
\hline No & Produksi & Cacat & presentase & Proporsi & UCL & LCL \\
\hline 1 & 85010 & 19056 & 1,96 & 0,2241618633 & 0,21419 & 0,20911 \\
\hline 2 & 88103 & 37373 & 3,85 & 0,424196678 & 0,14116 & 0,20365 \\
\hline 3 & 73936 & 13847 & 1,42 & 0,1872835966 & 0,21449 & 0,19962 \\
\hline 4 & 74100 & 14307 & 1,47 & 0,1930769231 & 0,21448 & 0,20676 \\
\hline 5 & 73331 & 15078 & 1,55 & 0,2056156332 & 0,21451 & 0,20004 \\
\hline 6 & 81320 & 13322 & 1,37 & 0,163821938 & 0,21428 & 0,19914 \\
\hline 7 & 59136 & 13488 & 1,39 & 0,2280998444 & 0,24502 & 0,10476 \\
\hline
\end{tabular}


[61] Fatma, Artikel Ilmiah (Tugas Akhir), Prodi Manajemen Fakultas Ekonomi Unanda

\begin{tabular}{|c|c|c|c|c|c|c|}
\hline 8 & 74762 & 13340 & 1,37 & 0,1784328937 & 0,21446 & 0,19422 \\
\hline 9 & 92265 & 14936 & 1,53 & 0,1618815369 & 0,21402 & 0,20000 \\
\hline 10 & 88611 & 15960 & 1,64 & 0,1801130785 & 0,21410 & 0,20032 \\
\hline 11 & 100380 & 21744 & 2,24 & 0,2166168559 & 0,21385 & 0,20171 \\
\hline 12 & 78984 & 19523 & 2,01 & 0,2472905905 & 0,21434 & 0,20125 \\
\hline jumlah & 969938 & 211974 & 21,85 & 2.610591432 & 2.5289 & 2.32058 \\
& & & & & & \\
\hline
\end{tabular}

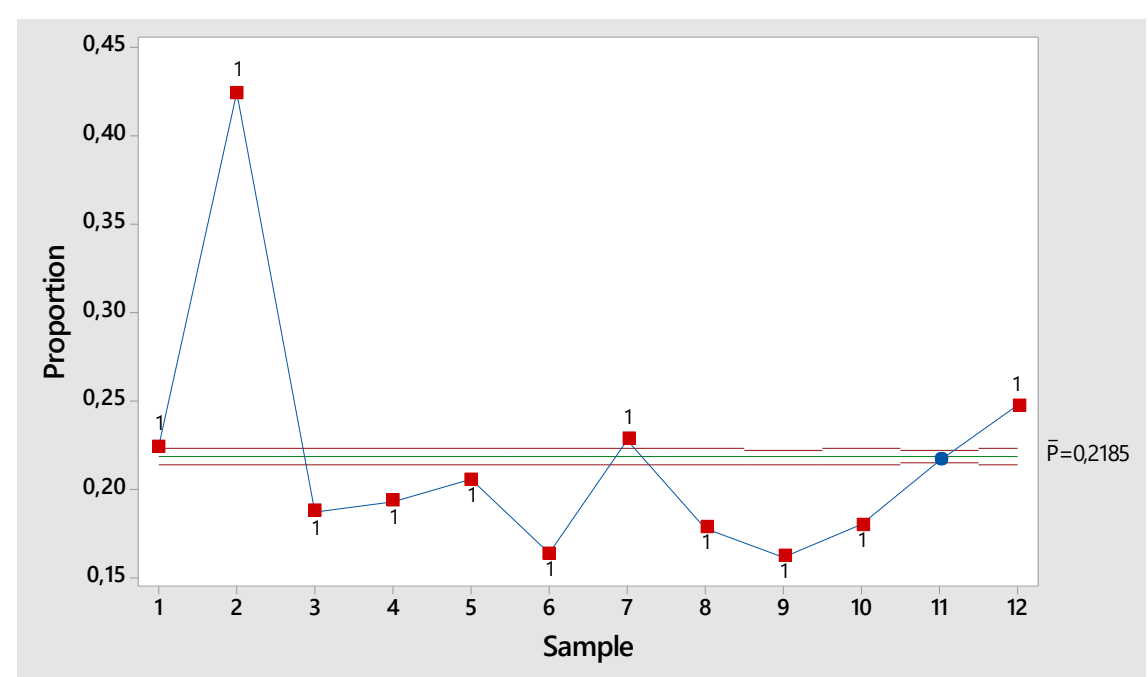

Gambar 2. Grafik kendali $p$

Control chart atau grafik kendali merupakan salah satu tools untuk mengukur apakah proses pengendalian kualitas produksi di PT. Asera Tirta Posidonia apakah berjalan dengan baik atau belum. Berdasarkan gambar 4 diatas dapat kita lihat bahwa terdapat titik-titik (point proporsi grafik) batas kendali UCL dan LCL dan terdapat 1 titik yang berada dalam kondisi In Control (diluar batas kendali) dan ada 11 titik-titik yang berada pada kondisi Out Control (diluar batas kendali) tersebut sehigga perlu dilakukan perbaikan yang maksimal agar jumlah cacat tidak melewati batas control yang telah ditentukan.

\subsection{Pembahasan}

Biaya kualitas adalah biaya yang terjadi atau mungkin akan terjadi karena kualitas yang buruk. Biaya ini pada umumnya berhubugan dengan penciptaan kualitas, pengidentifiksian, perbaikan ,dan pencegahan perubahan. Biaya kualitas perlu dikelola sedemikian rupa untuk mencapai suatu tingkat kualitas agar produk yang dibuat atau jasa yang diserahan sesuai dengan spesifiasi rancangan dan bebas dari cacat atau masalah yang akan mempengaruhi penampilan atau kinerja yang diukur dengan kesesuainnya terhadap keinginan pelanggan.

Biaya pencegahan (prevention cost) ini terjadi dalam rangka kegiatan untuk menghindarkan adanya produk cacat dalam proses produksi. Biaya ini terjadi sebelum dan selama proses produksi langsung. Biaya pencegahan 
merupakan biaya yang terjadi untuk mencegah kerusakan produk yang dihasilkan, meliputi: teknik dan perencanaan kualitas, peninjauan produk baru, rancangan proses atau produk, pengendalian proses, pelatihan, dan audit kualitas. Biaya deteksi/penilaian adalah biaya yang terjadi untuk menentukan apakah produk sesuai dengan persyaratan-persyaratan kualitas yang ditetapkan sebelumnya.

Kelompok biaya deteksi/penilaian meliputi: biaya-biaya yang terjadi untuk mengidentifiksi produk cacat,termasuk inspeksi dan pengujian produk, dan fungsi pengawasan kualitas lainnya. Kelompok ini juga meliputi: biaya pemeriksaan dan pengujian bahan baku yang dibeli, pemeriksaan dan pengujian produk, pemeriksaan kualitas produk, dan evaluasi persediaan. Secara singkat biaya penilaian yang biasa juga disebut biaya inspeksi yang terjadi dalam hubungannya dengan proses untuk mencegah agar tidak terdapat produk cacat sebelum produk dikirim kepada para pelanggan.

Jadi biaya kualitas tersebut

Tabel 2, menujukkan bahwa jumlah produksi yang di lakukan setiap bulannya tidaklah sama. hal tersebut di karenakan dalam menentukan jumlah produk yang akan di produksi oleh prusahaan di dasarkan pada order yang terima perusahaan. Adapun rata-rata prouksi perbulan 3879752 pcs dengan rata-rata perdos 80828,2 atau sekitar 0,5 dari total produksi setiap bulan. Sesuai dengan sasaran mutu PT. Asera Tirta Posidonia bahwa produk di katakan berkualitas apabila tercapai kesesuaian antara peoduksi yang di hasilkan dengan rencana target standar atau sasaran mutu yang ditetapkan oleh perusahaan pada setiap awal produksi atau target produk cacat adalah tidak lebih dari $1 \%$.

Untuk memperoleh hasil pengendalian kualitas yang efektif, maka pengendalian terhadap kualitas suatu produk dapat dilaksanakan dengan menggunakan teknik-teknik pengendalian kualitas, karena tidak semua hasil produksi sesuai dengan standar yang telah ditetapkan. Terdapat beberapa standar kualitas yang bias ditentukan oleh perusahaan dalam upaya menjaga output barang hasil produksi diantaranya, standar kualitas bahan baku yang akan digunakan; standar kualitas proses produksi (mesin dan tenaga kerja yang melaksanakannya); standar kualitas barang setengah jadi; standar kualitas barang jadi; dan standar administrasi, pengepakan dan pengiriman produk akhir tersebut sampai ke tangan konsumen.

Pada histogram Gambar 1 digunakan untuk melihat banyaknya produksi yang cacat dalam bentuk diagram batang agar mudah membaca atau menjelaskan dengan cepat maka data tersebut perlu untuk disajikan dalam bentuk histogram yang berupa alat penyajian data dalam bentuk grafis balok. Dari hasil histogram diatas menunjukkan bahwa pada bulan 1 menampilkan produk cacat sebanyak 19056 dan pada bulan 2 terjadi kerusakan yang sangat parah pada produk tersebut sebanyak 37373 , bulan ke 3 sebanyak 13847, bulan ke 4 sebanyak 14307, bulan 5 sebanyak 15078, bulan 6 sebanyak 13322, selanjutnya pada bulan 
7 sebanyak 13488, dan pada bulan 8 terjadi penurunan produk rusak yaitu sebanyak 13340, dan pada bulan 9 sebanyak 14936, dan pada bulan 10 sebanyak 15960, pada bulan 11 sebanyak 21744, dan pada bulan 12 sebanyak 19523. Jadi hanya bulan 2 yang mengalami kerusakan yang sangat parah dalam tahun 2016 . Gambar 2 Peta kendali $P$ mempunyai manfaat untuk membantu pengendalian kualitas produksi serta dapat memberikan informasi mengenai kapan dan dimana perusahaan harus melakukan perbaikan kualitas. Dengan bantuan program computer dapat diperoleh print out berupa grafik.

Berdasarkan Gambar 2 diatas dapat kita lihat bahwa terdapat titik-titik (point proporsi grafik) batas kendali UCL dan LCL dan terdapat 1 titik yang berada dalam kondisi In Control (diluar batas kendali) dan ada 11 titik-titik yang berada pada kondisi Out Control (diluar batas kendali) tersebut sehigga perlu dilakukan perbaikan yang maksimal agar jumlah cacat tidak melewati batas control yang telah ditentukan.

Dari hasil yang didapatkan bahwa pengendalian biaya kualitas untuk mengurangi produk cacat PT. Asera Tirta Posidonia Kota Palopo menggunakan analisis menghitung total biaya kualitas dan jumah optimal, menghitung total produk cacat/rusak, menghitung garis pusat Central Line (CL), menghitung batas kendali bawah atau Upper Control Limit (UCL), dan menghitung batas kendali bawah atau Lower Control Limit (LCL). Yang hasilnya bahwa biaya kualitas yang tinggi mampu mengurangi produk cacat PT. Asera Tirta Posidonia Kota Palopo berarti hipotesis dapat di terima.

\section{Kesimpulan}

Dari hasil yang didapatkan bahwa pengendalian biaya kualitas untuk mengurangi produk cacat PT. Asera Tirta Posidonia Kota Palopo menggunakan analisis menghitung total biaya kualitas dan jumah optimal, menghitung total produk cacat/rusak, menghitung garis pusat Central Line (CL), menghitung batas kendali bawah atau Upper Control Limit (UCL), dan menghitung batas kendali bawah atau Lower Control Limit (LCL) menunjukkan bahwa biaya kualitas yang tinggi mampu mengurangi produk cacat PT. Asera Tirta Posidonia Kota Palopo untuk tahun 2016 dengan total biaya kualitas Rp 27.854.052 dan jumlah produksi optimal sebesar 696.379 perdos setiap bulan. Adapun saran yaitu (a) manajemen pengendalian mutu lebih meningkatkan frekuensi pemeriksaan untuk mengurangi jumlah produk rusak walaupun harus menanggung biaya kualitas yang tinggi; (b) meningkatkan pelayanan terhadap konsumen misalnya dengan memberikan jaminan kualitas terhadap produk yang di berikan kepada pelanggan hal ini perlu di lakukan agar konsumen atau pelanggan tetap setia kepada perusahaan, mengingat adanya persaingan yang semakin ketat; dan (c) melakukan pengendalian kualitas secara terus menerus, agar jumlah produk rusak/cacat dapat diminimalkan menjadi lebih kecil. 
[64 ] Fatma, Artikel Ilmiah (Tugas Akhir), Prodi Manajemen Fakultas Ekonomi Unanda

\section{Daftar Pustaka}

Al Azhar, A. (2012). Peranan Total Quality Manajemen (TQM) Dalam Meningkatkan Daya Saing. PEKBIS (Jurnal Pendidikan Ekonomi Dan Bisnis), 2(01).

Ariani, D. W. (2004). Pengendalian kualitas Statistik (Pendekatan kuantitatif dalam manajemen kualitas). Yogyakarta: Andi.

Badri, S. (2012). Pengendalian Kualitas Produk Dengan Pendekatan Model SQC (Statistical Quality Control) (Aplikasi Model Pada Perusahaan Furniture). Hasil Penelitian.

Didiharyono, D. (2016). Penerapan Metode Statistical Processing Control Untuk Menganalisis Pengendalian Kualitas Produk pada PT. Asera Tirta Posidonia. Jurnal Equilibrium, 2(4), 325-332.

Didiharyono, D., Marsal, M., \& Bakhtiar, B. (2018). Analisis Pengendalian Kualitas Produksi Dengan Metode Six-Sigma Pada Industri Air Minum PT Asera Tirta Posidonia, Kota Palopo. Sainsmat: Jurnal Ilmiah Ilmu Pengetahuan Alam, 7(2), 163-176.

Fauzan, A. (2018). Analisis Biaya Kualitas Untuk Meningkatkan Produktivitas Dalam Penerapan Total Quality Management di PT. Kali jaya putra Sidoarjo (Doctoral dissertation, University of Muhammadiyah Malang).

Gasperz, Vincent. 2005. Total Quality Management. Jakarta: PT. Gramedia Pustaka Utama.

Haryono, D. (2017). Pengendalian kualitas produksi dengan model grafik kontrol P pada PT. Asera Tirta Posidonia. Jurnal Varian, 1(1), 27-34.

Irwan, I., \& Haryono, D. (2015). Pengendalian Kualitas Statistik (Pendekatan Teoritis dan Aplikatif). Bandung: Alfabeta.

Sari, N. K. R., \& Purnawati, N. K. (2018). Analisis Pengendalian Kualitas Proses Produksi Pie Susu Pada Perusahaan Pie Susu Di Kota Denpasar. INOBIS: Jurnal Inovasi Bisnis dan Manajemen Indonesia, 1(3), 290-304.

Suti, M. (2011). Strategi peningkatan mutu di era otonomi pendidikan. Jurnal Medtek, 3(2), 1-6.

Wahyuningtias, K. A. (2013). Pengaruh Biaya Kualitas Terhadap Produk Rusak Pada CV. Ake Abadi. Jurnal EMBA: Jurnal Riset Ekonomi, Manajemen, Bisnis dan Akuntansi, 1(3). 